Bangladesh J. Bot. 37(1): 67-74, 2008 (June)

\title{
MORPHOLOGY, ANATOMY, ECOLOGY AND PALYNOLOGY OF TWO CENTAUREA SPECIES FROM TURKEY
}

\author{
SEZgin CeliK ${ }^{*}$, IsMet Uysal ${ }^{1}$ and Yusuf MENEMEN ${ }^{2}$ \\ Department of Technology Programs, Kirlkkale Vocational School, \\ Kirikkale University, Kirikkale, Turkey \\ Key words: Morphology, Anatomy, Ecology, Pollen, Centaurea spp.
}

\begin{abstract}
Centaurea L. sect. Ptosimopappa, a local endemic group in the Mediterranean and South East Anatolia, is represented by only two species, namely C. ptosimopappa Hayek and C. ptosimopappoides Wagenitz in Turkey. Both these species show a very restricted distribution as serpentine habitat indicators and are recorded as vulnerable. Present study was carried out to enlighten the morphological, anatomical and ecological features of these two species in detail. The structure of achene, indumentum and pollen grains were investigated by using Scanning Electron Microscope (SEM). The capitulum, involucre and leaf structure of these two species are rather similar, but their achenes and pollen grains differ from each other. In C. ptosimopappa pollen spinules are densely distributed but in C. ptosimopappoides they are sparsely distributed. The achenes are obovate in C. ptosimopappa and rectangular in C. ptosimopappoides. C. ptosimopappa is a scrub species but $C$. ptosimopappoides is a subscrub species. A negative relation in terms of the proportion of sand to silt content of the soil and positive relation between the percentage of $\mathrm{CaCO}_{3}$ and $\mathrm{pH}$ was observed for $C$. ptosimopappa $(\mathrm{p}<0.05)$. A negative relation in terms of the proportion of sand to silt content of the soil was observed in C. ptosimopappoides $(\mathrm{p}<0.01)$.
\end{abstract}

\section{Introduction}

The genus Centaurea has about 800 species with the Mediterranean area and SW Asia as its centres of diversity (Wagenitz and Hellwig, 1996). In Turkey it is represented by 187 taxa of which 114 are endemics (Wagenitz 1975, Uzunhisarcikli et al. 2005 and Aytac and Duman 2005). High endemism ratio shows that Turkey is one of the gene centers of this genus. Its medicinal importance, as antidiabetic, antidiarrhoeal, antirheumatic, antiinflammatory, colagog, choleretic, digestive, stomachic, diuretic, menstrual, astringent, hypotensive, antipyretic, sitotoxic, antibacterial, has been widely emphasized by several workers (Orallo et al. 1998, Arif et al. 2004 and Güven et al. 2005). Some studies have been carried out on the chemical analysis of Turkish endemics C. ptosimopappoides and C. ptosimopappa (Oksuz and Serin 1997, Celik et al. 2005a). Both these species show a very restricted distribution as serpentine habitat indicators and are recorded as vulnerable. As such, a comparative study was undertaken in order to present a detailed morphological, anatomical and ecological features of these two species. The structure of achene, indumentum and pollen was also investigated using SEM.

\section{Material and Metods}

The specimens of C. ptosimopappa Hayek were collected from Hatay, Amanos Mountains above Dörtyol, at 850-950 m, Yahyali Yaylasi and that of C. ptosimopappoides Wagenitz from Adana, Aladag, at $1500 \mathrm{~m}$. The herbarium specimens were deposited in the Department of Biology, Canakkale Onsekiz Mart University with their voucher numbers, Celik 2148-2165.

*Corresponding author: sezgin_celik@yahoo.com, ${ }^{1}$ Department of Biology, Faculty of Science and Arts, Canakkale Onsekiz Mart University, Canakkale,Turkey. ${ }^{2}$ Department of Biology, Faculty of Science and Arts, Kirikkale University, Kirikkale, Turkey. 
The morphological observations and biometric measurements were made on fresh and also with herbarium specimens. The collected data were evaluated statistically. The pollen grains were obtained from dried herbarium specimens. Several unopened buds (to make sure alien pollen grains were not present) were placed in a watch glass and squashed adding a few drops of wetting agent. These were transferred to copper stubs, with double-sided adhesive tape and then coated with gold for 5-6 minutes. The pollen grains were examined using Jeol $100 \times$ CXII Scanning Electron Microscope and the terminology of Punt et al. (1994) was adopted.

The wax-embedding procedure was followed for studying the anatomy of root, stem and leaf. Plant parts were first fixed by using FAA according to Menemen and Jury's (2001) procedure. The samples were passed through an alcohol and histoclearing series for dehydration. Paraplast was added to the histoclearing solution and the samples were placed in an oven. Cross sections of root, stem and leaf were taken with the help of a rotary microtome at $7 \mu \mathrm{m}$ thickness and stained with safranin and crystal violet. Investigations were carried out under a light microscope and photomicrographs were taken by a photomicrography apparatus (JENA).

Soil specimens (0-50 cm deep) were collected from 13 points of $2000 \mathrm{~m}^{2}$ area where the plant specimens were growing. These were analysed for physical and chemical parameters according to the methods outlined by Ozturk et al. (1997).

\section{Results and Discussion}

Nearly 300 species of the genus Centaurea are problematic and none of the early attempts to subdivide the genus has been widely accepted (Bremer 1994, Wagenitz and Hellwig 1996, GarciaJacas et al. 2006). Investigations were made on the morphology, anatomy, palynology, phytogeographic distrubution and ecology of Centaurea species in Turkey (Pehlivan 1994, Pinar and Inceoglu 1996, Pehlivan 1996, Kaya et al. 2000, Reeves and Adigüzel 2004, Celik 2005a,b, Uysal 2005a,b). However, no study has been reported on the C. ptosimopappa and C. ptosimopappoides which are recorded as vulnerable in the Red Data Book of Turkey (Ekim et al. 2000).

Both C. ptosimopappa and C. ptosimopappoides are perennial. C. ptosimopappa is a shrub, 1.20 - $2.15 \mathrm{~m}$ tall, with ascending glabrous branches. Leaves are firm, almost leathery, glabrous on both surfaces, woolly at the margin. The leaves of sterile shoots are crowded at the top of branches, lanceolate-ovate to obovate, narrowed into a petiole, $10-17 \times 3.5-5 \mathrm{~cm}$, whereas the leaves of flowering shoots are much smaller and narrower, uppermost partly enveloping capitula. Capitula lie on \pm inflated peduncles. Involucre is $15-30 \times 10-18 \mathrm{~mm}$, narrowly ovoid, phyllaries very numerous, glabrous, adpressed and appendage is a minute deciduous $0.3-0.5 \mathrm{~mm}$ spinule. Flowers yellow, marginal not radiant. Achenes $4.6 \pm 0.9 \mathrm{~mm}$ long, $3.7 \pm 0.6 \mathrm{~mm}$ broad, obovate with deciduous, $4 \mathrm{~mm}$ long pappus. Flower between April and August.

C. ptosimopappoides is a subshrub, with stems c. 20-65 cm tall, erect or ascending, simple or with a few long branches. Leaves are firm with slightly prominent lateral nerves, glabrous on both surfaces, slightly tomentose at magrin, entire, lanceolate, basal and lower petiolate, obovate, 11-15 $\times 2-5 \mathrm{~cm}$, upper ones sesile, smaller. Involucre 14-25 $\times 12-16 \mathrm{~mm}$, narrowly ovoid and appendage is a short $0.5-1.5 \mathrm{~mm}$. Flowers yellow, marginal not radiant. Achenes $5.6 \pm 1.9 \mathrm{~mm}$ long, $3.4 \pm 0.6$ $\mathrm{mm}$ broad, rectangular, pappus semideciduous and 6-11 mm long, inner row not distinct. Flower between June and July.

Although capitula in the flowers of these two species are very similar to each other but $C$. ptosimopappa is a shrub and C. ptosimopappoides is a subshrub. Our observations revealed that in C. ptosimopappa flowering stem is taller, leaves are lanceolate-ovate to obovate, involucre is bigger, achene is smaller, obovate, and pappus too is smaller and deciduous. In C. ptosimopappoides leaves are lanceolate, involucre is smaller but long, rectangular and pappus 
is semideciduous and longer. A comparison of the morphological characters of C. ptosimopappa and C. ptosimopappoides with those that were given in the Flora of Turkey (Davis 1975) shows that there are many discrepancies in the findings (Table 1 ).

Table 1. Comparison of Centaurea ptosimopappa and C. ptosimopappoides for their morphological features.

\begin{tabular}{|c|c|c|c|c|}
\hline & \multicolumn{2}{|c|}{ Centaurea ptosimopappa } & \multicolumn{2}{|c|}{ Centaurea ptosimopappoides } \\
\hline & Flora of Turkey & $\begin{array}{c}\text { Present } \\
\text { observations }\end{array}$ & Flora of Turkey & Present observations \\
\hline $\begin{array}{l}\text { Flowering } \\
\text { stem }\end{array}$ & Shrub, $1-1.80 \mathrm{~m}$ & Shrub, $1.20-2.15 \mathrm{~m}$ & Subshrub, 30-50 cm & Subshrub, 20-65 cm \\
\hline Leaves & $\begin{array}{l}\text { Lanceolate-spathulate } \\
\text { to obovate, } \\
12-15 \times 2.5-3 \mathrm{~cm}\end{array}$ & $\begin{array}{l}\text { Lanceolate-ovate } \\
\text { to obovate, } \\
10-17 \times 3.5-5 \mathrm{~cm}\end{array}$ & $\begin{array}{l}\text { Lanceolate, basal and } \\
\text { lower petiolate, } \\
10-13 \times 1-2 \mathrm{~cm}\end{array}$ & $\begin{array}{l}\text { Lanceolate, basal } \\
\text { and lower petiolate, } \\
\text { obovate, } \\
11-15 \times 2-5 \mathrm{~cm}\end{array}$ \\
\hline Involucre & $18-30 \times 8-16 \mathrm{~mm}$ & $15-30 \times 10-18 \mathrm{~mm}$ & $18-22 \times 9-11 \mathrm{~mm}$ & $14-25 \times 12-16 \mathrm{~mm}$ \\
\hline Achene & 4-5 mm & $\begin{array}{l}4.6 \pm 0.9 \mathrm{~mm} \text { long, } \\
3.7 \pm 0.6 \mathrm{~mm} \\
\text { broad, obovate }\end{array}$ & $5-7 \mathrm{~mm}$ & $\begin{array}{l}5.6 \pm 1.9 \mathrm{~mm} \text { long, } \\
3.4 \pm 0.6 \mathrm{~mm} \text { broad, } \\
\text { rectangular }\end{array}$ \\
\hline Pappus & $\begin{array}{l}\text { Very deciduous, 4-6 } \\
\text { mm }\end{array}$ & $\begin{array}{l}\text { Deciduous, } \\
5-9 \mathrm{~mm}\end{array}$ & $\begin{array}{l}\text { Deciduous and } \\
5-8 \mathrm{~mm}\end{array}$ & $\begin{array}{l}\text { Semideciduous and } \\
6-11 \mathrm{~mm}\end{array}$ \\
\hline
\end{tabular}

Root anatomy shows that plants have a disintegrated periderm on the outermost layer as a protective tissue. C. ptosimopappa has cortex tissue with ordered, flattened and thin walled parenchymatic cells, with groups of sclerenchyma cells in the cortex tissue. The cortex tissue consists of 10-23 layers and occupies a wide arcade up to the endodermis. But endodermis and pericycle are not easily distinguished. C. ptosimopappoides has cortex tissue with disordered, oval-shaped and thin walled parenchymatic cells. The cortex in C. ptosimopappoides has sparsely placed groups of sclerenchyma cells with 4-9 cells and is composed of 20-30 layers. In both the species, vascular bundles and cambium are very similar. Phloem takes up a small part of the bundles, in contrast to the xylem which is located all around the parenchymatous pith in $C$. ptosimopappa, but pith is filled with the elements of metaxylem in C. ptosimopappoides. In both the species, pith rays lie in the cortex and cambium in a depressed form and has 2-3 layers. The phloem occupies a small part in the vascular bundles, whereas xylem with tracheids, trachea and sclerenchymatic cells covers a majour part of the bundles (Fig.1a, b).

Stem anatomy is almost identical in both the species, except for chlorenchymatous tissue, with 3-5 layers in C. ptosimopappa and 2-3 in C. ptosimopappoides. In both the species, the stem has a thin cuticle layer, followed by a single layered epidermis and papilla like ejections and mesophytic amaryllis-type stomata. Vascular bundles are scattered in a circular manner below the parenchymatous tissue. The phloem, as in the roots, occupies a small area and xylem makes up most of bundles, which are surrounded with sclerenchymatous tissue. The cambium is 2 layered. The pith is of parenchymatous cells (Fig. 2a,b).

Anatomical features of leaves of two species are identical. The leaves are amphystomatic with sparsely single eglandular hairs of equifacial type, in which 2-3 layers of palisade parenchyma are found on both sides of spongy parenchyma, occupying a small part in the middle, as in other xerophytes. A wavy cuticle lies on upper and lower sides of epidermis, with mesophytic stomata. The bundle is surrounded by a single parenchymatous cell layer, the largest bundle is in the midvein and secretory canals lie in the leaf mesophyll (Fig. 3a, b ). 

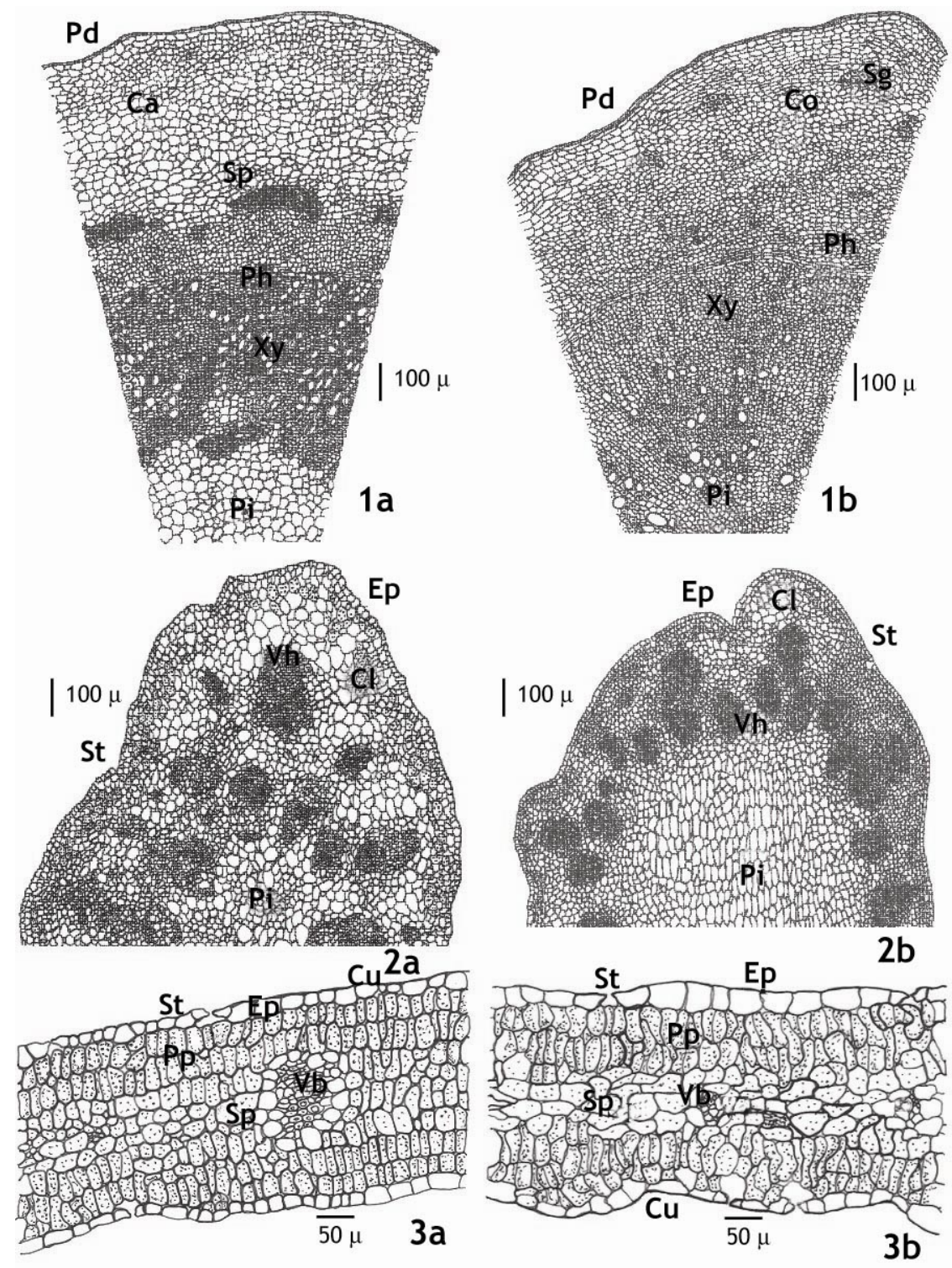

Figs. 1-3: Photomicrographs: Cross sections of root in (1a) C. ptosimopappa and (1b) C. ptosimopappoides. (Pd: Periderm, Co: Cortex, Ph: Phloem, Sg: Sclerenchymatous cells, Xy: Xylem, Pi: Pith). Cross sections of stem in (2a) C. ptosimopappa and (2b) C. ptosimopappoides. (Ep: Epidermis, Cl: Chlorenchymatous tissue, Vb: Vascular bundle, St: Stomata Pi: Pith). Cross sections of leaf in (3a) C. ptosimopappa and (3b) in C. ptosimopappoides (Ep: Epidermis, St: Stomata, Cu: Cuticle, Pp: Palisade parenchyma, Sp: Spongy parenchyma, Vb: Vascular bundle).

C. ptosimopappa pollen grains are tricolporate with a polar axis (P) 35.19 - $45.39 \mu \mathrm{m}$, equatorial axis (E) 25.93 - $28.46 \mu \mathrm{m}, \mathrm{P} / \mathrm{E} 1.36$ - 1.59, prolate; colpi tapering at both ends; spinulose, spinules densely distributed, width of the spinules at base (W) $1.56 \mu \mathrm{m}$, height of the 
spinules $(\mathrm{H}) 1.09 \mu \mathrm{m}, \mathrm{W} / \mathrm{H}$ 1.43, apices sharp, with basal and subapical distinct perforations irregularly distributed.

The achene in this species are obovate, adpressed above, swollen below narrows towards the apex, apex blunt, $4.6 \pm 0.9 \mathrm{~mm}$ long, $3.7 \pm 0.6 \mathrm{~mm}$ broad, with pappus, $3.8 \pm 0.8 \mathrm{~mm}$ long. Achene cells in unarranged lines, wall of middle and side cells not much thick, surface not hairy, part attached to the capitulum exactly semicircular.

C. ptosimopappoides pollen grains are tricolporate; polar axis (P) 33.85 - $39.63 \mu \mathrm{m}$, equatorial axis (E) 25.39 - $25.15 \mu \mathrm{m}, \mathrm{P} / \mathrm{E} 1.33$ - 1.41, prolate; colpi tapering at both ends; spinulose, spinules sparsely distributed, width of the spinules at base (W) $3.53 \mu \mathrm{m}$, height of the spinules $(\mathrm{H}) 1.47 \mu \mathrm{m}, \mathrm{W} / \mathrm{H}$ 2.40, apices very sharp, with basal and subapical distinct perforations, irregularly distributed.
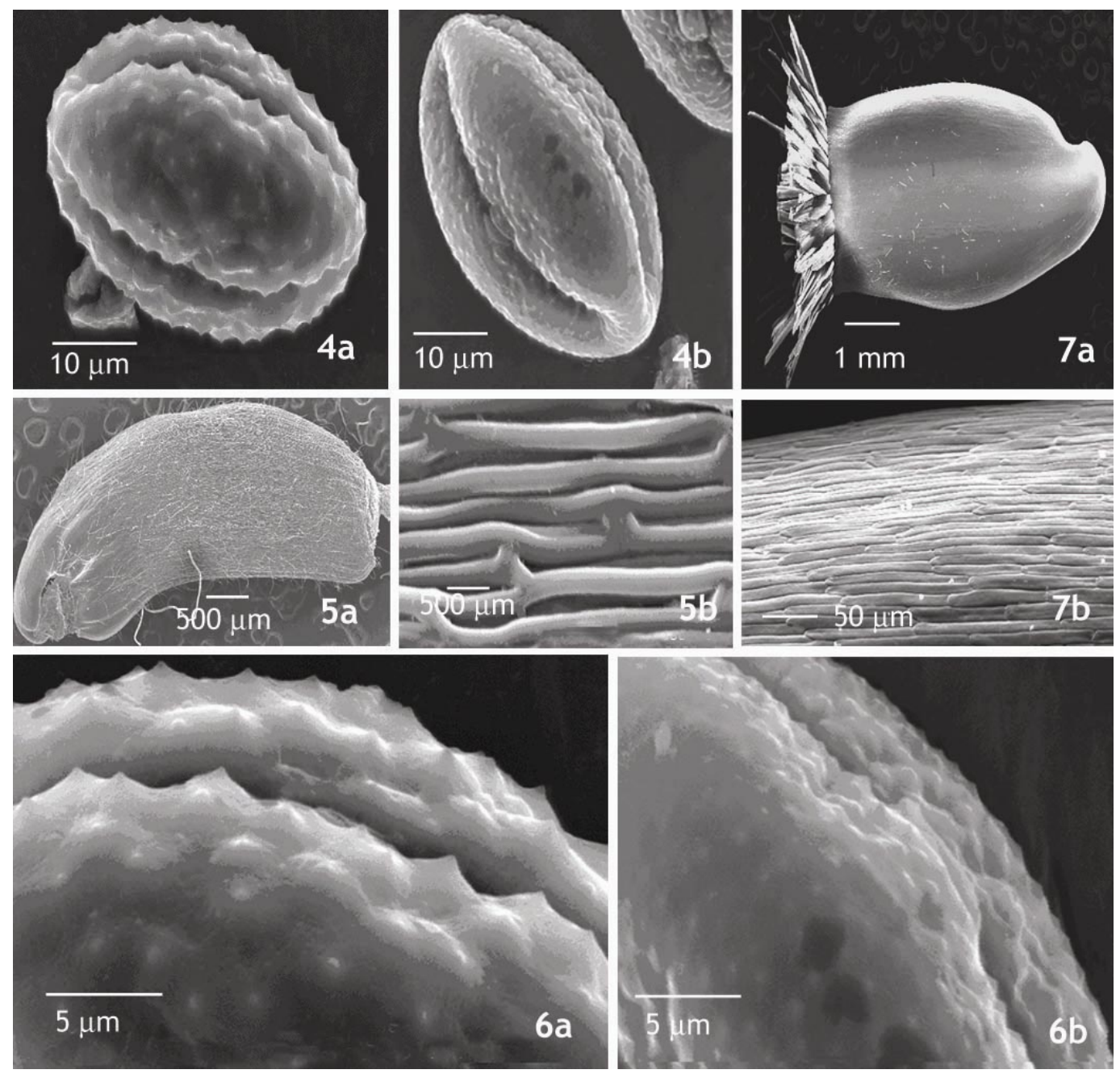

Figs. 4-7: SEM. 4a-b. Pollen grains of C. ptosimopappa. Achene structure of C. ptosimopappa. General view (5a), detailed achene surface (5b). Pollen grains of $C$. ptosimopappa. Spinules at apex (6a) and equatorial view (6b). Achene structure of C. ptosimopappaoides. General view (7a), detailed achene surface (7b). 
Achenes in this species are rectangular, swollen above, sunken below and slightly narrow towards the apex, apex circular (rotundat), $5.6 \pm 1.9 \mathrm{~mm}$ long, $3.4 \pm 0.6 \mathrm{~mm}$ broad, with deciduous pappus, $3.8 \pm 0.8 \mathrm{~mm}$ long. Cells of achene in unarranged lines, wall of middle and side cells not much thick, surface with simple sparse hairs, part attached to the capitulum exactly semicircular.

C. ptosimopappa and C. ptosimopappoides show a very restricted distribution in the Mediterranean and the South East Anatolian parts of Turkey.

C. ptosimopappa is found in the Pinus brutia and Carpinus orientalis forests. The species of Arbutus andrachne, Cotinus coggygria, Erica manipuliflora, Myrtus communis, Pistacia terebinthus, C. amanicola, C. spicata, Ferulago cassia, Isatis amam, I. davisii and Onosma cassium occur as its associates in these areas. Centaurea ptosimopappa prefers serpentine forests growing under high himudity. It is a serpentine endemic and a hyperaccumulator of nickel (Reeves and Adiguzel 2004). The area abounds in limestone, ultrabasic serpentine and peridotite. The soils show $52.15 \pm 2.1 \%$ of sand, $23.21 \pm 2.0 \%$ of silt and $24.64 \pm 1.4 \%$ of clay, EC $185.6 \pm 23 \mathrm{dS} \mathrm{m}^{-1}$, pH 7.17 $\pm 0.15, \mathrm{CaCO}_{3} 3.49 \pm 0.50 \%$, organic matter $3.85 \pm 0.48 \%, \mathrm{~N} 0.45 \pm 0.02 \%$, P $60.5 \pm 3.1$ ppm, $\mathrm{K}^{+} 375.5 \pm 18 \mathrm{ppm} \mathrm{Ca}^{+} 1981 \pm 358 \mathrm{ppm} \mathrm{Mg} 299 \pm 36 \mathrm{ppm}, \mathrm{Na}^{+} 36.4 \pm 5.4$ ppm, $\mathrm{Fe}^{++} 9079$ $\pm 302 \mathrm{ppm}, \mathrm{Mn}^{++} 3250 \pm 360 \mathrm{ppm}, \mathrm{Zn}^{++} 62.7 \pm 2.1 \mathrm{ppm}$ and $\mathrm{Cu}^{++} 45.4 \pm 2.8 \mathrm{ppm}$. A negative correlation was determined in terms of the proportion of sand to silt content of the soil $(\mathrm{p}<0.05)$ and positive correlation between $\mathrm{CaCO}_{3}$ and $\mathrm{pH}$ for $C$. ptosimopappa.

C. ptosimopappoides occurs in Pinus brutia forests. The associates of this species are Alkanna amana, Alyssum syriacum, Aristolochia brevilabris, Erodium absinthoides ssp. haradjianii, Origanum brevidens, Cistus creticus, Myrtus communis ssp. communis, Laurus nobilis, Phillyrea latifolia ssp. orientalis, Pistada lentiscus, Silene amana, Tanacetum depauperat and Thlaspi syriacum. C. ptosimopappoides forms wide communities on hillsides and serpentine rocks. The physico-chemical features of soils are as follows: sand $59.14 \pm 1.8 \%$, silt $27.52 \pm$ $2.3 \%$, clay $13.33 \pm 1.2 \%$, EC $192.1 \pm 18 \mathrm{dS} \mathrm{m}^{-1}$, pH $7.57 \pm 0.54, \mathrm{CaCO}_{3} 6.21 \pm 1.7 \%$, organic matter $2.73 \pm 0.34 \%$, N $0.30 \pm 0.03 \%$, P $22 \pm 2.6 \mathrm{ppm}, \mathrm{K}^{+} 172.1 \pm 20 \mathrm{ppm}, \mathrm{Ca}^{+} 2767 \pm 512 \mathrm{ppm}$, $\mathrm{Mg}^{+} 651 \pm 74 \mathrm{ppm}, \mathrm{Na}^{+} 57.9 \pm 6.4 \mathrm{ppm}, \mathrm{Fe}^{++} 14525 \pm 843 \mathrm{ppm}, \mathrm{Mn}^{++} 3850 \pm 440 \mathrm{ppm}, \mathrm{Zn}^{++} 58.9$ $\pm 2.2 \mathrm{ppm}$ and $\mathrm{Cu}^{++} 53.0 \pm 2.3 \mathrm{ppm}$. A negative correlation occurs in terms of the proportion of sand to silt content of the soil ( $\mathrm{p}<0.01)$.

Previous descriptions of C. ptosimopappa and C. ptosimopappoides were supplemented and corrected in the light of the new observations on these plants in their habitats. The root anatomy of these species shows variations which may have a taxonomic significance. The pollens in $C$. ptosimopappa and C. ptosimopappoides are tricolporate with colpi tapering at both ends and spinulose. Spinules in C. ptosimopappa are densely distributed and in C. ptosimopappoides they are sparsely distributed. Tricolporate feature of the pollen grain is identical with those of the other Centaurea species (Uysal et al. 2005 a,b; Celik et al. 2005 a,b). Achene in C. ptosimopappa Differs from that of C. ptosimopappoides. The ecological features show that physical and chemical features are very similar to those of previous studies, but the levels of $\mathrm{Zn}^{++}$indicate high limestone, ultrabasic serpentine and peridotite main rock (Celik et al. 2005a,b, Uysal et al. 2005 a,b).

Rarity is a normal feature of all biological communities with most species assemblages comprising a few abundant species and many with only a few individuals (Rabinowitz et al. 1986, Gaston 1994).The impact of humans on natural ecosystems has resulted in the formation of a new suite of rare species that were previously more abundant but are now rare because of human disturbances. The species of C. ptosimopappa and C. ptosimopappoides are under a heavy pressure of grazing in their distribution areas, because both the species have no spines on capitulum and stem. These species have been recorded as vulnerable IUCN 2004 (Ekim et al. 2000) as such, there is a need for their in situ conservation for the increase of their population. 


\section{References}

Arif, R., E. Küpeli and F. Ergun. 2004. The biological activity of Centaurea L. species (Review), Gazi Univ. J. Sci. 17(4): 149-164.

Aytac, Z. and H. Duman. 2005. A new species of Centaurea L. (Compositae) from Turkey. Pak. J. Bot. 37(3): 563-566.

Bremer, K. 1994. Asteraceae. Cladistics and Classification. Timber Press, Portland. pp. 625-680.

Celik, S., I. Uysal and Y. Menemen, 2005a. Centaurea species in Turkey (A): Centaurea odyssei Wagenitz (Asteraceae) in Kazdagi (Mt. Ida) National Park. Intl. J. Biodiver. Sci. and Manag. 1(2): 113-120.

Celik, S., I. Uysal, Y. Menemen, and E.Karabacak. 2005b. Morphology, anatomy, ecology, pollen and achen structure of Centaurea consanguinea DC. (Sect. Acrolophus) in Turkey. Intl. J. Bot. 1(1):85-89.

Davis, P.H. 1975. Flora of Turkey and the east Aegean Islands. Edinburgh Univ. Press, Edinburgh, UK. pp. 559.

Ekim, T., M. Koyuncu, M. Vural, H. Duman, Z. Aytac and N. Adiguzel. 2000. Red Data Book of Turkish Plants (Pteridophyta and Spermatophyta), Bariscan Press, Ankara. pp. 246.

Garcia-Jacas, N., T. Uysal, K. Romashchenko, V.N. Suarez-Santiago, K. Ertugrul and A. Susanna. 2006. Centaurea Revisited: A molecular survey of the Jacea Group, Ann. Bot. 98(4): 741-753.

Gaston, K.J. 1994. Rarity. Chapman and Hall, London. pp. 205.

Guven, K., S. Celik and I. Uysal. 2005. Antimicrobial activity of five endemic Centaurea L. species. Pharmaceut. Biol. 43 (1): 67-71.

Kaya, Z., S.E. Basaran and U. Akkemik. 2000. Palynological research on some endemic species of Centaurea L. in Turkey. BIOS (Macedonia, Greece) 5: 27-34.

Menemen, Y. and S.L. Jury. 2001. A taxonomic revision of the genus Pastinaca L. (Umbelliferae). Israel J. Plant Sci. 49: 67-77.

Oksuz, S. and S. Serin. 1997. Triterpenes of Centaurea-Ptosimopappoides. Phytochem. 46(3): 545-548.

Orallo, F., M. Lamela, M. Camina, E. Uriatre and M. Calleja. 1998. Preliminary sudy of the potential vasodilator effects on rat aorta of centaurein and centaureidin, two flavonoids from Centaurea corcubionensis. Planta Med. 64(2): 116-119.

Ozturk, M., M. Pirdal and F. Ozdemir. 1997. Plant Ecology. Ege Univ. Press, Bornova-Izmir. pp.129.

Pehlivan, S. 1994. Scanning electron microscopic studies of the polen grains of some Turkish endemic Centaurea. J. Fac. Pharm. Gazi 11(2): 205-211.

Pehlivan, S. 1996. Light microscopic studies in the pollen morphology of some endemic Turkish Centaurea. Turkey J. Bot. 20: 311-321.

Pinar, M.N. and O. Inceoglu. 1996. A comparative study on the pollen morphology of Centaurea triumfettii All. Groups. A, B and C with light and electron microscopy. Turkey J. Bot. 20: 395-399.

Punt, W., S. Blackmore, S. Nilsson and A. Thomas. 1994. Glossary of pollen and spore terminology. LPP Foundation, Utrectht, The Nederlands. pp. 1-72.

Rabinowitz, D., S. Cairns and T. Dıllon. 1986. Seven forms of rarity and their frequency in the flora of the British Isles. In: Conservation Biology: The science of scarcity and diversity (M. E. Soulé Ed.), pp. 182-204. Massachusetts, USA.

Reeves, R.D. and N. Adiguzel. 2004. Rare plants and nickel accumulators from Turkish serpentine soils, with special reference to Centaurea species. Turkey J. Bot. 28: 147-153.

Uysal, I., S. Celik and Y. Menemen. 2005a. Centaurea species in Turkey (B): Comparative studies of two closely related species, C. kurdica Reichardt and C. sclerolepis Boiss.. International J. Biodiv. Sci. and Manag. 1(2): 121-128.

Uysal, I., S. Celik and Y. Menemen. 2005b. Morphology, Anatomy, Ecology, Pollen and Achene Features of Centaurea polyclada DC. (Sect. Acrolophus) in Turkey. J. Biol. Sci. 5(2): 176-180.

Uzunhisarcıklı, M.E., M. Teksen and E. Dogan. 2005. Centaurea marashica (Asteraceae), a new species form Turkey. Ann. Bot. Fennici 42: 309-312. 
Wagenitz, G. and Hellwig FH. 1996. Evolution of characters and phylogeny of the Centaureinae. In: Compositae: Systematics. Proceedings of the International Compositae Conference (D.J.N. Hind and H.G. Beentje Ed.), pp. 491-510. Royal Botanic Gardens, Kew.

Wagenitz, G. 1975. Centaurea L. In: Flora of Turkey and the east Aegean Islands, Vol. 5. (P.H. Davis Ed.), pp. 559. Edinburgh Univ. Press, Edinburgh.

(Manuscript received on 5 April, 2007; revised on 5 September, 2007) 